\title{
Piotr Hus
}

Uniwersytet Warszawski

\section{Wspólnota znaczeń czy nowoplemię? Etnograficzne badania warszawskiej społeczności couchsurfingowej}

W wadziłem w latach 2012-2014 ${ }^{1}$. Porządek prezentowanej pracy będzie następujący: w pierwszej kolejności postaram się przybliżyć Czytelnikowi, czym jest couchsurfing oraz wytłumaczę znaczenie statusu wspólnoty, jaki mu nadaję. Później opiszę metodologię przeprowadzonych badań oraz założenia teoretyczne, ze szczególnym uwzględnieniem kluczowej dla tego artykułu koncepcji „wspólnoty znaczeń” Anthony'ego P. Cohena. Następnie, bazując na materiale etnograficznym, przybliżę obraz tego, czym jest couchsurfing i couchsurfer według członków społeczności couchsurfingowej, podejmę temat podróżowania przy użyciu couchsurfingu oraz opiszę warszawską społeczność couchsurfingową. W dalszej części tekstu przedstawię rozwój funkcjonowania społeczności couchsurfingowej w czasie, skupiając się przede wszystkim na jej organizacyjnych przemianach i ich konsekwencjach. Na koniec zastanowię się nad tym, która z teorii dotyczących pojęcia wspólnoty najlepiej oddaje specyfikę couchsurfingu.

\section{Czym jest couchsurfing?}

Couchsurfing.com jest stroną internetową założoną w 2003 r. przez młodego Amerykanina Caseya Fentona. Jest ona jedną z wielu istniejących dziś sieci społecznościowych, określanych jako hospitality services. Sieci te zrzeszają osoby szukające oraz oferujące bezpłatny nocleg. Jest to więc forma turystyki alternatywnej - zamiast korzystać z konwencjonalnych form zakwaterowania osoby zarejestrowane na stronie przyjmowane są w mieszkaniu innego członka

1 Badania zostały przeprowadzone $\mathrm{w}$ ramach programu studiów licencjackich na kierunku Etnologia i Antropologia Kulturowa UW. Ich wynikiem była praca licencjacka, obroniona we wrześniu 2015 r., pod kierunkiem dr Karoliny Bielenin-Lenczowskiej. Praca dostępna jest w Archiwum IEiAK UW. 
społeczności, dzięki czemu mają okazję poznać odwiedzane miejsca niejako "oczami" osób mieszkających tam na co dzień. Choć już w ubiegłym stuleciu istniały podobne inicjatywy ${ }^{2}$, to bez wątpienia największy rozkwit sieci gościnności przypada na XXI wiek, co związane jest z upowszechnieniem się Internetu. Powstają wtedy trzy portale mogące pochwalić się dziś największą liczbą użytkowników, czyli Hospitality Club (2000), Couchsurfing (2002) oraz Bewelcome (2007). Zdecydowanie najpopularniejszym z nich jest dzisiaj Couchsurfing.com, który zrzesza około 10 milionów użytkowników.

\section{Couchsurfing jako wspólnota}

„Nawet to, co dziś najbardziej zbliża się do »wspólnoty« odbiega daleko od sytuacji, którą rozważali Tónnies i Durkheim, gdy odwoływali się do Gemeinschaft lub mechanicznej solidarności" pisze Małgorzata Dmochowska (2012: 63). Jak słusznie zauważa badaczka, wspólnoty tradycyjne, charakteryzujące się trwałością, ekskluzywnością, bezwarunkowym charakterem przynależności, wspólnotą terytorialną czy silną rolą tradycji, różnią się w sposób oczywisty od współczesnych społeczności internetowych, takich jak Couchsurfing.com. Chcąc uchwycić specyfikę grup organizujących się w przestrzeni online, warto pochylić się nad koncepcją „ wspólnoty wyobrażonej” ukutej przez amerykańskiego historyka Benedicta Andersona (1997). Zgodnie z nią wspólnota nie musi wcale oznaczać wspólnoty pochodzenia, zamieszkania czy historii. Warunkiem, aby można było o niej mówić, jest natomiast istnienie poczucia więzi wśród członków danej grupy. Fundamenty tego uczucia mogą nadal zasadzać się na wspólnym języku, historii czy pochodzeniu, jak w przypadku wspólnot tradycyjnych, ale równie dobrze mogą mieć związek na przykład ze wspólnymi zainteresowaniami bądź celami. Inną istotną cechą takich wspólnot, która łatwo daje się odnieść do wielomilionowej społeczności couchsurferów, jest ich "wyobrażony" charakter: „członkowie nawet najmniejszego narodu nigdy nie znają większości swych rodaków, nie spotykają ich, nic o nich nie wiedzą a mimo to pielęgnują w umyśle obraz wspólnoty" (Anderson 1997: 19). Przytoczony tu cytat zdradza, że Andersonowskie pojęcie „wspólnot wyobrażonych" wiąże się ściśle z koncepcją narodu, w związku z czym zastosowanie myśli Andersona do analizy społeczności internetowych wiąże się nieuchronnie z ograniczeniami na poziomie teorii oraz metodologii. Niemniej jednak pewne cechy „wspólnot wyobrażonych", które tutaj przywołałem (a które, jak jeszcze zobaczymy, pokrywają się ze specyfiką omawianej grupy), stanowiły grunt pod późniejsze teorie, które jeszcze lepiej pozwalają oddać naturę społeczności doby Internetu.

2 Już w 1949 r. powstał Servas International - pozarządowa organizacja non profit zrzeszająca gospodarzy oraz podróżujących. Portal powstał jako odpowiedź na tragedię II wojny światowej - jego pacyfistyczny charakter oraz podkreślanie chęci budowania ogólnoświatowego dialogu $\mathrm{z}$ poszanowaniem praw człowieka będą od tej pory widoczne $\mathrm{w}$ filozofii większości powstających później podobnych sieci, z Couchsurfing.com włącznie. 
Szczególnie ciekawego kontekstu do rozważań na temat couchsurfingu dostarcza myśl francuskiego socjologa Michela Maffesolego (2008) dotycząca charakteru współczesnych wspólnot. Odwołam się do niej szerzej w trakcie omawiania materiału etnograficznego, gdyż stanowi ona dobrą ilustrację procesów zachodzących w obrębie omawianej społeczności. Termin „wspólnota”, którym posługuję się $\mathrm{w}$ odniesieniu do omawianej grupy, oprócz inspiracji myślą Benedicta Andersona i Michela Maffesolego, związany jest również z koncepcją „wspólnoty znaczeń" Anthony'ego P. Cohena (2003). Ze względu na kluczowe znaczenie myśli tego brytyjskiego antropologa w procesie kształtowania się mojej teoretycznej i metodologicznej perspektywy, temat „wspólnoty znaczen" rozwijam szerzej w części „Założenia teoretyczne”.

Pisząc o couchsurfingu jako wspólnocie, nie można zapomnieć o roli, jaką odgrywa w niej zaufanie. Większość teoretyków zgadza się bowiem co do tego, że stanowi ono podstawowy element współczesnego życia społecznego, potrzebny do budowania trwałych relacji społecznych. David Good pisze: "codzienne życie społeczne, które uznajemy za naturalne, jest bez zaufania po prostu niemożliwe" (za: Sztompka 2007: 12). W zależności od założeń badawczych oraz skali ujęcia zjawiska zaufanie definiowane było w różny sposób. Benjamin Barber pisze na przykład, że na zaufanie składają się „społecznie nabyte i potwierdzone oczekiwania, jakie ludzie żywią wobec siebie nawzajem, wobec instytucji i organizacji, wśród których żyją, oraz wobec moralnych reguł życia społecznego, które ustalają podstawowe zasady ich życia" (za: Frykowski 2007: 14). Powyższa definicja ujmuje problematykę zaufania całościowo, w ujęciu systemowym. Możemy też przedstawić omawiane zjawisko w węższym planie, stwierdzając, że „zaufanie jest zakładem podejmowanym na temat niepewnych, przyszłych działań innych ludzi" (Sztompka 2007: 70). Na użytek niniejszego artykułu obydwa ujęcia przedstawiają wartość operatywną. Pierwsze z nich podkreśla rolę wspólnych norm i wartości przestrzeganych przez couchsurferów i będzie miało szczególne znaczenie przy okazji omawiania struktury couchsurfingu. Drugie natomiast ma wymiar jednostkowy i jego zastosowanie widzę w kontekście analizy diadycznych relacji, czyli formy interakcji, która dominuje w społeczności couchsurfingowej (relacja pomiędzy osobą goszczoną a goszczącą).

Duże znaczenie zaufania znajduje również swoje potwierdzenie $\mathrm{w}$ publikacjach dotyczących couchsurfingu. $\mathrm{W}$ ostatnich latach możemy obserwować rosnące zainteresowanie badaczy omawianą społecznością. Najczęściej podejmowane $\mathrm{w}$ pracach zagadnienia dotyczą z jednej strony analizy couchsurfingu jako alternatywnej formy turystyki (np. Gnevosa 2011; Picard 2013), a z drugiej właśnie mechanizmów wytwarzania się i funkcjonowania zaufania $w$ obrębie społeczności (np. Lauterbach 2009; Rosen 2011).

W tym kontekście należy podkreślić znaczenie, jakie odgrywa sam portal Couchsurfing.com. Dostarcza on bowiem zestawu narzędzi umożliwiających budowanie sieci zaufania. Wśród tych narzędzi kluczową rolę odgrywa konto użytkownika. Profil jest cennym źródłem informacji na temat naszego 
potencjalnego surfera ${ }^{3}$ ( $w$ języku couchsurfingowym surfer to osoba, która jest goszczona przez innego członka wspólnoty) lub hosta (osoby, która przyjmuje w swoim mieszkaniu innego użytkownika). Informacje w nim zawarte to imię, nazwisko i wiek użytkownika, miejsce pochodzenia i zamieszkania, miejsce i data ostatniego logowania, informacja na temat daty zarejestrowania się na stronie, znajomości języków, wykształcenia, a także dane pozwalające potencjalnym hostom i surferom ocenić, czy znajdą wspólną płaszczyznę porozumienia; do wypełnienia są między innymi takie rubryki, jak „o mnie”, "filozofia”, ,zainteresowania”, ,"muzyka, filmy i książki”, , ,odwiedzone kraje”, , ,jedna wyjątkowa rzecz, którą zrobiłem/zrobiłam" oraz "co mogę zaoferować gospodarzom" (wiedza i doświadczenia, którymi chcę się podzielić ze swoim hostem). Ponadto na profilu opisana jest sytuacja mieszkaniowa surfera (lokalizacja i przestrzeń przeznaczona dla gościa) oraz zasady panujące w mieszkaniu.

Poza samym opisem istnieje jeszcze kilka elementów odgrywających istotną rolę $\mathrm{w}$ budowaniu wizerunku użytkownika. Jednym $\mathrm{z}$ nich są zamieszczane zdjęcia - często z couchsurfingowych podróży. Jeszcze ważniejsze są tak zwane referencje, czyli opinie wystawiane użytkownikowi przez osoby, które gościły bądź były goszczone przez danego członka społeczności. Referencje przybierają formę opisu doświadczeń ze spotkania z couchsurferem, a ogólne wrażenie podsumowuje się poprzez wybranie jednej z trzech kategorii: "pozytywne", "neutralne" bądź „negatywne". Posiadanie choćby jednej negatywnej referencji zdecydowanie obniża status profilowy potencjalnego surfera bądź hosta.

W końcu, przeglądając konto użytkownika, widzimy czy jest „zweryfikowany". Poddanie się weryfikacji jest płatne (choć nieobowiązkowe) i polega na potwierdzeniu swojego miejsca zamieszkania poprzez dokonanie przelewu bankowego z karty, na której widnieje imię, nazwisko oraz adres osoby dokonującej transakcji. W odpowiedzi na wskazany adres otrzymuje się kod aktywacyjny, po którego wprowadzeniu na koncie użytkownika pojawia się informacja, że dany użytkownik został zweryfikowany.

\section{Metodyka badań}

W ramach badań przeprowadziłem 28 pogłębionych wywiadów z couchsurferami, którzy w trakcie badań mieszkali w Warszawie. Łącznie miałem okazję porozmawiać z przedstawicielami 11 krajów. Wśród moich rozmówców znalazło się 15 osób narodowości polskiej, 2 Hiszpanów, 2 Brazylijczyków, a także po jednej osobie z następujących krajów: Stany Zjednoczone, Anglia, Holandia, Włochy, Irlandia, Turcja, Chile i Japonia. Wśród couchsurferów, którzy zgodzili się na rozmowę, znalazło się 13 kobiet i 16 mężczyzn. Średnia długość prze-

\footnotetext{
3 Terminy, takie jak ",surfer”, ,"host”, ,"surfować”, ,"hostować”, ,couchrequest” oraz „freeloader", weszły na stałe do języka polskich couchsurferów, dlatego pozwalam sobie na operowanie powyższymi anglicyzmami.
} 
prowadzonych wywiadów wyniosła około 45 minut, zaś najdłuższy z nich liczył sobie 75 minut. Wywiady zostały przeprowadzone $w$ języku polskim (10), angielskim (15) i hiszpańskim (3); wszystkie były pogłębione i nieustrukturyzowane. Swobodzie zadawania pytań i udzielania odpowiedzi sprzyjał fakt nieformalnego charakteru relacji panujących między couchsurferami. Dodatkowo, jeszcze przed rozpoczęciem wywiadu, starałem się poświęcić około kwadransa na rozmowę, w trakcie której nie tylko przedstawiałem cel swoich badań, ale również starałem się zawiązać rozmowę na dowolny temat niezwiązany z moimi badaniami. Wydaje mi się, że ten zabieg pozwalał poczuć się swobodniej moim rozmówcom. Ponadto rozmowy były prowadzone $\mathrm{w}$ wybranej przez nich przestrzeni; $\mathrm{w}$ zależności od ich preferencji umawialiśmy się $\mathrm{w}$ warszawskich kawiarniach, w domu rozmówcy bądź w moim mieszkaniu.

Prowadziłem także obserwacje uczestniczące $\mathrm{w}$ trakcie licznych spotkań couchsurfingowych odbywających się w Warszawie. Tutaj niezwykle pomocna okazała się moja pozycja badawcza: od 2011 r. jestem członkiem couchsurfingu, zaś jeszcze przed rozpoczęciem badań uczestniczyłem od ponad roku w życiu warszawskiej społeczności, uczęszczając na spotkania oraz oprowadzając po mieście couchsurferów przyjeżdżających do Warszawy. Ponadto miałem okazję dwukrotnie wcielać się w rolę hosta, goszcząc couchsurferów z Chin i Holandii, oraz wielokrotnie podróżować przy użyciu couchsurfingu. Zdobyte doświadczenie pozwoliło mi zatem dużo szybciej odnaleźć się w przestrzeni badawczej; miało wpływ na łatwość nawiązywania kontaktów oraz na spontaniczny i swobodny charakter relacji z innymi couchsurferami w trakcie spotkań couchsurfingowych. Obecność na nich była więc dla mnie okazją do zaangażowania się w życie wspólnoty. Choć nie informowałem każdego z osobna o podwójnej roli, jaką odgrywałem w trakcie tych spotkań, to jednak często, rozmawiając w szerszym gronie, wspominałem, że prowadzę badania. Zazwyczaj spotykało się to $\mathrm{z}$ zainteresowaniem uczestników eventów i było okazją do znalezienia osób chętnych do rozmowy. W związku z tym zdecydowana większość moich rozmówców miała okazję poznać mnie jeszcze przed wywiadem, co było jeszcze jednym czynnikiem wpływającym pozytywnie na charakter rozmów.

Ważnym polem badań był również Internet. Przyglądałem się aktywnościom użytkowników na stronie warszawskiej społeczności couchsurferów oraz dokonałem analizy treści, których dostarcza portal: regulaminu, misji i wartości zapisanych w statucie strony. Na materiały, którymi się posłużyłem, złożyły się również artykuły prasowe, strony internetowe oraz blogi podejmujące temat couchsurfingu.

\section{Założenia teoretyczne}

Gdy dwa lata temu zaczynałem badania nad warszawską społecznością couchsurfingową, byłem już couchsurferem z trzyletnim doświadczeniem. Niemniej jednak mimo wielomiesięcznej przynależności do badanej grupy wiele kwestii 
wciąż pozostawało dla mnie niejasnych: Co tak naprawdę łączy użytkowników zarejestrowanych na portalu Couchsurfing.com? Jakim rysem osobowościowym charakteryzują się te osoby? Jak rozumieją społeczność, której są częścią? Co motywuje ich do uczestniczenia $\mathrm{w}$ tym międzynarodowym projekcie?

Dzisiaj, z perspektywy czasu, mogę powiedzieć, że powyższe pytania były efektem błędnych założeń na temat natury couchsurfingu. Zakładałem bowiem a priori wewnętrzną spójność społeczności. Stawiając sobie za cel wyszukanie zbioru wspólnych cech, które miałyby charakteryzować członków badanej grupy, w rzeczywistości z góry dokonałem ich esencjalizacji. Ponadto tak sformułowane pytania badawcze niosły za sobą implicite statyczne ujęcie społeczności.

Proces, który przeszedłem od tamtej pory, najprościej można ująć jako przejście od strukturalnego do symbolicznego potraktowania wspólnoty couchsurferów. Po wielu miesiącach manewrowania bez większego postępu przez labirynt strukturalnych ograniczeń, zapoznałem się wreszcie z książką Anthony'ego P. Cohena pt. The symbolic construction of community (1985). Zagadnienia, które ten brytyjski antropolog społeczny porusza w swoim dziele, uważam za kluczowe $\mathrm{w}$ kontekście zrozumienia natury społeczności couchsurfingowej. Cohen przedstawia tradycje myślowe, które jeszcze do II połowy XX wieku kształtowały sposób, w jaki socjologowie i antropologowie ujmowali zjawisko wspólnoty. Najprościej mówiąc, dominowało przekonanie, iż rzeczywistość społeczna jest zewnętrzna w stosunku do jednostki. To zaś wiązało się z założeniem, że struktura danej grupy determinuje zachowanie jej członków; osoby podobnie ulokowane w strukturze społecznej miały zachowywać się w ten sam sposób i nadawać swoim zachowaniom te same znaczenia. Jak zauważa Cohen, takie podejście wykluczało możliwość wewnętrznej różnorodności w obrębie grupy, prowadząc do esencjalizacji postaw.

Na poziomie metodologii przełamanie tego deterministycznego myślenia wiązało się z przeniesieniem akcentu ze struktury na znaczenia oraz na ekspresję owych znaczeń - symbolikę. Owo przesłanie badacz ubiera w szaty istnego manifestu: „Wspólnota nie może już nigdy więcej być trafnie opisana w kategoriach jej instytucji i komponentów, gdyż teraz uznajemy ją za symbol, któremu różni jej uczestnicy przypisują własne znaczenia. Wszyscy oni mogą wyrażać swoje współuczestnictwo w tej samej wspólnocie, używać tego samego słowa, ale dopasowują je do własnych, niepowtarzalnych doświadczeń i osobowości" (Cohen 2003: 195). Nie znaczy to oczywiście, że dawniej badacze społeczni w ogóle nie dostrzegali tego rodzaju braku zgodności w obrębie społeczności. Niemniej jednak nie traktowano obecności owej polifonii znaczeń jako immanentnej właściwości wspólnot, lecz - wręcz przeciwnie - jako antytezę wspólnotowości, jako przejaw braku równowagi wewnętrznej. Zgodnie $z$ arbitralnie narzuconą gramatyką zakładającą, że „struktura determinuje znaczenie” uznawano, że jeśli wśród członków danej społeczności zaczyna brakować jednomyślności, to taka sytuacja skutkuje niewydolnością $\mathrm{w}$ kierowaniu zachowaniami jednostek i może prowadzić do załamania danego systemu norm, a nawet do zaniku więzi społecznej. 
Emil Durkheim taki stan osłabienia bądź wzajemnej sprzeczności norm społecznych określał mianem „anomii".

Natomiast według Cohena przynależność jest związana nie tyle z zachowaniem i działaniem, co z pewną wspólnotą znaczeń i nie musi ona oznaczać jednomyślności. Zapewnienie ciągłości grupy wiąże się natomiast według Cohena z uniwersalną cechą interakcji międzyludzkich:

\begin{abstract}
Jako członkowie społeczeństwa jesteśmy wszyscy nieustannie zaangażowani w walkę o zrozumienie zachowań innych ludzi. To co uchodzi za rozumienie, jest często oparte na interpretacji, a interpretacja polega głównie na rekonstrukcji zachowania innych ludzi przez pryzmat naszych własnych zachowań (...) Stąd, jeśli inni ludzie posługują się takimi samymi słowami jak my, interpretujemy ich zamierzone znaczenie, zakładając, że koresponduje ono z naszym. Czasem może ono korespondować, niekiedy zaś nie, ale nawet gdy nie ma owej zgodności, możemy być całkiem nieświadomi jej braku - jak w przypadku wspólnoty współwyznawców postępujących na pierwszy rzut oka identycznie i wierzących w to "samo" (Cohen 2003: 194).
\end{abstract}

To, o czym mówi brytyjski antropolog, psychologowie społeczni określają mianem efektu fałszywej jednomyślności (false-consensus effect). Za jego istnieniem przemawiają liczne badania przeprowadzone przez takich psychologów społecznych, jak Lee D. Ross (1977).

Refleksja nad proponowanym przez Cohena rozumieniem wspólnoty pozwoliła mi uświadomić sobie, że to, co na początkowym etapie badań uważałem za wewnętrzną sprzeczność, było po prostu zestawem negocjowanych w obrębie grupy znaczeń. Zacząłem rozumieć społeczność couchsurferów jako wspólnotę znaczeń i zastanawiać się nad poszczególnymi aspektami tego konceptualnego modelu. Zgłębiałem kwestię wspólnych couchsurfingowych symboli, badałem ścieżki, którymi dokonuje się ich transmisja, wsłuchiwałem się $\mathrm{w}$ polifonię symboliki oraz obserwowałem konkretne działania i zachowania będące przejawami nadawania indywidualnych znaczeń. W końcu zdołałem też uchwycić całą gamę symbolicznych zachowań mających na celu przywrócenie granicy wspólnoty, której podstawy, jak wynika z moich badań, są na dzień dzisiejszy mocno osłabione. Wszystkie te wątki omawiam w niniejszym artykule.

\title{
Wyobrażenia na temat couchsurfingu i sylwetki couchsurfera
}

Dwa główne aspekty odzwierciedlające znaczenia, jakie couchsurferzy nadają symbolom, to wyobrażenia na temat sylwetki couchsurfera oraz kwestia tego, jak użytkownicy rozumieją sam projekt couchsurfingowy. Jedno z pytań, które postawiłem wszystkim rozmówcom, brzmiało: "Co pomyślałeś/ pomyślałaś, gdy pierwszy raz dowiedziałeś/dowiedziałaś się o istnieniu couchsurfingu?".

W ten sposób chciałem zachęcić rozmówców, którzy nierzadko zdążyli już dokonać naturalizacji wielu elementów rzeczywistości couchsurfingowej, aby 
spróbowali przywołać emocje i myśli, które im wtedy towarzyszyły. W odpowiedzi najczęściej mogłem usłyszeć takie określenia w odniesieniu do projektu couchsurfingowego, jak "dziwne”, „ryzykowne”, "niebezpieczne” czy nawet "szalone". Rozmówcy wymieniali potencjalne zagrożenia związane z podróżowaniem przy użyciu couchsurfingu, takie jak możliwość kradzieży oraz gwałtu. Wielu z nich nie rozumiało, jak ludzie mogą zaufać drugiemu człowiekowi do tego stopnia, że decydują się przyjąć pod swój dach zupełnie obcą osobę. Oczywiście nie we wszystkich rozmówcach projekt couchsurfingowy wzbudził poznawczy niepokój - część z nich odczuła ekscytację na myśl o podróżowaniu w taki sposób i, nie zastanawiając się długo, wyruszyła w pierwszą, spontaniczną, couchsurfingową wyprawę. Nawiasem mówiąc, sam jestem przykładem takiej osoby.

Z relacji moich rozmówców wynika, że doświadczenia couchsurfingowe mają moc zmieniania ludzi. Jedną z najczęściej sygnalizowanych zmian było nabranie większej ufności do ludzi w wyniku pozytywnych doświadczeń w kontaktach z innymi couchsurferami; osoby, z którymi rozmawiałem, spotykały się z dużą otwartością i bezinteresownością ze strony poznanych przez couchsurfing osób. Jedna z rozmówczyń zdradza na przykład:

Dzięki couchsurfingowi otwierasz się na ludzi (...) spotykasz ludzi w tramwaju, obcych i masz to podejście jednak, którego się nauczyłeś na couchu, że ta osoba na pewno będzie dobra i umówisz się z kimś na kawę, i tak dalej, mimo że może wcześniej bym tego nie zrobiła (M-27-Japonia) ${ }^{4}$.

W kontekście konceptualizacji granic wspólnoty ciekawiło mnie, czy moi rozmówcy dokonują rozróżnienia między couchsurferami a "resztą świata". Zadając to pytanie, miałem okazję poznać cały repertuar możliwych postaw. Pewna część rozmówców - przykładem może być couchsurferka, której wypowiedź przytoczyłem powyżej - deklaruje wysoki poziom zaufania i otwartości do ludzi, bez względu na to, czy są couchsurferami. Miałem jednak okazję rozmawiać i z takimi osobami, które stawiają wyraźną granicę między couchsurferami a ludźmi niezarejestrowanymi na stronie. $\mathrm{W}$ przypadku jednej $\mathrm{z}$ moich rozmówczyń rozróżnienie to wiąże się z przekonaniem, że couchsurferzy są bardziej otwarci na innych i tolerancyjni. W trakcie naszej rozmowy Zofia stwierdziła w pewnym momencie: „ja naprawdę postrzegam ludzi jako... Boże jak to było... że świat jest podzielony na ludzi, którzy są couchsurferami i którzy nimi nie są" (K-38-Polska), Zofia podzieliła się ze mną ciekawym doświadczeniem, które pozwoliło jej uświadomić sobie ten fakt. Moja rozmówczyni już od jakiegoś czasu chodziła na zajęcia tanga - cotygodniowe wydarzenie couchsurfingowe. W związku z bezpłatnym charakterem spotkań właściciel lokalu, w którym odbywały się zajęcia, licząc na dodatkowe dochody, poczynił kroki w celu promocji wydarze-

4 Pierwsza litera oznacza płeć (K - kobieta, M - mężczyzna), cyfra oznacza wiek respondenta, podany jest także kraj pochodzenia. 
nia również wśród ludzi nienależących do couchsurfingu. Spotkało się to z dużym niepokojem mojej rozmówczyni:

W pewnym momencie okazało się, że na następne zajęcia przyjdzie tak gdzieś z 60 nowych osób i muszę powiedzieć, że ja się bałam tego doświadczenia (...) żyję w takim przekonaniu, że ludzie spoza couchsurfingu są prawdopodobnie mniej otwarci na innych, mniej akceptujący innych, na przykład mnie, bo ja jestem dosyć niskiego wzrostu (K-38-Polska).

W podobnym tonie wypowiada się także couchsurferka Aldona, charakteryzując sylwetkę couchsurfera:

Jest osobą dużo bardziej otwartą na świat niż przeciętny człowiek, sam jak gdyby darzy ludzi dużo większym kredytem zaufania, więc też jest łatwiej być w pewnym sensie sobą, bo taka osoba nie bardzo sądzi, znaczy taka osoba nie bardzo jest judgemental (K-28-Polska).

Dla innych natomiast pytanie o dokonywaniu podziału na couchsurferów i całą resztą jest zwyczajnie źle postawione, ponieważ couchsurfing stał się ich sposobem na życie. Takim couchsurferem jest 34-letni Andrzej, który stwierdza:

Tak naprawdę większość moich znajomych $\mathrm{w}$ tej chwili to są właśnie couchsurfingowcy, w jakimś tam stopniu właśnie... swój ciągnie do swego, tak? Jeśli poznałeś kulturę osób otwartych na świat to już jakoś się nie wpasujesz do kultury, która ma bardzo ograniczone spojrzenie na niego, tak? Już będzie cię to uwierało w jakiś tam sposób (M-34-Polska).

Bardzo dobrze znaczenie wspomnianej przez Andrzeja "kultury otwartości” ilustruje wypowiedź jednej z warszawskich couchsurferek - Alicji, dla której, podobnie jak dla Andrzeja, couchsurfing stał się swoistą filozofią życia. Owa filozofia wiąże się natomiast z charakterem interakcji międzyludzkich, które odznaczać się mają ciekawością, tolerancją, otwartością, bezinteresownością i zaufaniem. Alicja zauważa:

bo couchsurfing to jest masa, masa ludzi, ty jesteś przyjaźnie nastawiony z założenia, bo jesteś na nich otwarty, a oni są otwarci na ciebie (...) Ten dystans jest maksymalnie... on nawet nie jest skrócony, on jest po prostu usunięty, tego dystansu nie ma, bo inaczej to by nie hulało... dlatego couchsurfing ma wielką siłę, że ci, którzy raz to przeżyli, to $\mathrm{w}$ tym chętnie zostają mimo tego, że zmieniają się im... to jest jak choroba, taki prawdziwy, prawdziwy couchsurfing, kiedy rzeczywiście doznasz tego obcowania z innymi ludźmi, doznasz tego zrozumienia, jak to wpływa na twoje życie (K-30-Polska).

W powyższej wypowiedzi, podobnie jak w wypowiedzi Andrzeja, można zauważyć, że zdobywanie doświadczenia couchsurfingowego jest pewnym procesem, który stopniowo zmienia człowieka - couchsurfer wypracowuje w sobie 
specyficzne nastawienie do świata i innych ludzi. Jest to jednocześnie swoisty rytuał przejścia:

jeśli poznałeś kulturę osób otwartych na świat, to już jakoś się nie wpasujesz do kultury, która ma bardzo ograniczone spojrzenie na niego, tak? Już będzie cię to uwierało w jakiś tam sposób (M-34-Polska).

Różne głosy, które tutaj prezentuję, ujawniają kilka płaszczyzn, na których couchsurferzy mogą odbierać swoje uczestnictwo w społeczności. Jedni rysują jasną granicę między couchsurferami a "całą resztą", odnajdując w bezpiecznych murach couchsurfingu swój azyl. Dla innych couchsurfing jest po prostu społecznością podróżników, a jeszcze dla innych filozofią życia. Jeszcze inne rozumienie projektu prezentuje Daniel - couchsurfer z Irlandii. Dla niego couchsurfing jest znakiem nowej kultury otwartości i wymiany, która rodzi się jako odpowiedź na agresywny system kapitalistyczny wytwarzający bariery między ludźmi i nie pozostawiający miejsca na bezinteresowność:

Myślę, że jest to bardzo pozytywny znak na przyszłość, w której moglibyśmy organizować się między sobą, bez konieczności pośrednika (...) Robimy to po prostu peer to peer, na poziomie platformy couchsurfingowej. Tego właśnie nam potrzeba w dzisiejszej kulturze (K-34-Irlandia).

Powyższe wizje nie wyczerpują jeszcze całego repertuaru konceptualizacji, których dokonują couchsurferzy. Pozostałe zaobserwowane przeze mnie sposoby rozumienia couchsurfingu podejmę $\mathrm{w}$ dalszej części tekstu, pisząc o podróżowaniu przy użyciu couchsurfingu oraz analizując życie warszawskiej społeczności couchsurfingowej.

\section{Podróżowanie przy użyciu couchsurfingu}

Jakkolwiek piszę ten tekst z zamiarem pokazania, że pod terminem „couchsurfing" kryje się dużo więcej niż tylko alternatywna forma turystyki, to wciąż hostowanie i surfowanie od początku były i nadal pozostają centralnymi aktywnościami wśród couchsurferów, a zarazem główną motywacją do uczestnictwa $\mathrm{w}$ tej międzynarodowej społeczności.

Zgodnie z profilem "wzorowego" surfera i hosta, wpisanym w sekcji "tips" na stronie couchsurfing.com, ważną motywacją do podróżowania za pomocą couchsurfingu powinna być szeroko rozumiana wymiana kulturowa. Relacja host-surfer powinna odznaczać się między innymi ciekawością, otwartością na drugą osobę oraz chęcią wspólnego spędzania czasu. Kontrafigurą ",wzorowego" surfera jest tak zwany freeloader, czyli osoba, która traktuje couchsurfing jedynie $\mathrm{w}$ kategoriach portalu umożliwiającego znalezienie darmowego noclegu. Wielu użytkowników ucieleśniających pierwotne wartości przekazywane przez couchsurfing, widząc, że freeloadersi stanowią coraz większe zagrożenie dla symbo- 
licznych granic wspólnoty, zaczyna podejmować przeróżne kroki w celu ograniczenia tego zjawiska. Na stronie społeczności warszawskiej powstają grupy dyskusyjne, na których użytkownicy zastanawiają się, jak poradzić sobie z tym zjawiskiem. W rozmowach tych często poruszany jest wątek tak zwanych couchrequestów, czyli wiadomości wysyłanych do potencjalnych hostów z prośbą o ugoszczenie. Treść takiego zapytania odzwierciedla bowiem często intencje i nastawienie wysyłającej go osoby. Niespersonalizowane couchrequesty, czyli takie, w których brakuje bezpośredniego odniesienia do osoby hosta oraz argumentacji, dlaczego wysyłający zdecydował się napisać właśnie do tego użytkownika, z dużym prawdopodobieństwem pozwalają określić, że szukający noclegu nie zapoznał się z profilem hosta i nie jest zainteresowany ideą wymiany kulturowej. W tym świetle ciekawa jest propozycja, która pojawiła się na forum warszawskiej grupy. Dotyczyła ona ustalenia limitu czasowego uniemożliwiającego wysyłanie dwóch zapytań o kanapę w odstępie mniejszym niż pięć minut. To miałoby uniemożliwić "hurtowe" wysyłanie wiadomości o tej samej treści do kilkudziesięciu hostów, co jest częstą praktyką wśród freeloadersów. Innym zabiegiem stosowanym przez niektórych użytkowników jest zawieranie w opisie swojego profilu tak zwanego „keyword”, słowa klucza, które potencjalny surfer musi zamieścić $\mathrm{w}$ tytule zapytania o kanapę, aby jego wiadomość została rozpatrzona. W ten sposób host zyskuje pewność, że osoba prosząca o przenocowanie zapoznała się przynajmniej z jego profilem. Wielu couchsurferów w odpowiedzi na bezosobowe zapytanie o kanapę wysyła wiadomość z linkiem do podstrony couchsurfing.com, na której znajduje się pakiet wskazówek jak napisać dobrego couchrequesta. Punktem zapalnym jest również korzystanie z couchsurfingu podczas podróży służbowych oraz przy okazji przyjazdów na koncerty. Pierwsza sytuacja rodzi problemy natury moralnej - darmowy nocleg w trakcie podróży służbowej, za którą surfer dostaje pieniądze, jest według części rozmówców zarabianiem na czyjejś dobroci. Natomiast w przypadku koncertów couchsurfer ma jasno określony cel przyjazdu i zazwyczaj nie przyjeżdża sam, lecz z grupą znajomych. W związku z tym czas, który mógłby spędzić z hostem, jest ograniczony.

Oczywiście pomiędzy wzorowym hostem a freeloaderem istnieje cała gama pośrednich postaw. Nie dziwią mnie więc gorące dyskusje dotyczące tego, czy i kiedy powinniśmy zaakceptować zaproszenie osoby wysyłającej niespersonalizowane zapytanie o kanapę, czy posiadającej ubogo wypełniony profil. Użytkownicy bardziej elastyczni $\mathrm{w}$ tej kwestii powołują się na couchsurfingową wartość bezinteresowności. Na przykład jeden z moich rozmówców ubiera to w następujące słowa:

Wiem, że niektórzy ludzie jakby kierują się... kierunek tylko jeden, tak? Jak jedziesz do kogoś to powinieneś z nim spędzać czas (...) ale tak naprawdę wszystko zależy od sytuacji, w jakiej ludzie są, tak? Niektórzy potrzebują szybkiego noclegu i do tego Couchsurfing też się nadaje (M-34-Polska). 
Jest jednak również spora grupa couchsurferów trzymająca się bardziej tradycyjnych zasad; stoją oni na straży wartości, które obowiązywały od początku istnienia portalu, a które w dobie rosnącej liczby użytkowników ulegają coraz większemu rozmyciu. Takie osoby są świadome faktu, że przyjmowanie u siebie surferów posiadających ubogo wypełnione profile, przyjeżdżających w ramach podróży służbowej czy wysyłających niespersonalizowane zapytania o kanapę, przyczynia się do osłabiania i przesuwania granic wspólnoty.

W tym kontekście duże obawy budzi też ostatnio zjawisko poszukiwania relacji o charakterze seksualnym za pomocą portalu. Na stronie rejestrują się coraz częściej osoby, których celem jest znalezienie przygodnego partnera seksualnego, choć jeden z podstawowych punktów regulaminu strony głosi: „couchsurfing nie jest portalem randkowym" ${ }^{5}$. Z tego powodu ze względów bezpieczeństwa coraz mniej dziewczyn jest skłonnych przyjmować w domu surferów płci przeciwnej. Jednocześnie mężczyźni zwykle wolą gościć kobiety. W rezultacie samotnie podróżujący panowie zmagają się dziś z ogromnym problemem znalezienia noclegu na portalu Couchsurfing.com. Warto zauważyć, że w profilu istnieje możliwość ustalenia preferencji płci naszego gościa. Co ciekawe, zaznaczenie takiego priorytetu staje się kolejnym narzędziem sprzeciwu wobec dzisiejszej kondycji couchsurfingu w momencie, gdy mężczyźni ustalają priorytet dla couchsurferów, a nie couchsurferek, wiedząc, że tym pierwszym zdecydowanie trudniej byłoby znaleźć nocleg.

Jednym z ważniejszych wydarzeń na mojej drodze badawczej było uświadomienie sobie, że znaczna część dyskusji i sporów dotyczących kodeksu postępowania dotyczącego podróżowania za pomocą couchsurfingu, a w jeszcze większym stopniu kontrowersji obecnych na polu warszawskiej społeczności couchsurfingowej, w rzeczywistości ma swoje źródło w różnych odpowiedziach na jedno pytanie: $W$ jakim stopniu couchsurferem jest osoba mająca doświadczenie w podróżowaniu i goszczeniu za pomocą couchsurfingu, a w jakim stopniu termin ten określa po prostu człowieka, posiadającego pewne cechy wpisane w projekt couchsurfingowy, takie jak otwartość, życzliwość i bezinteresowność, niekoniecznie natomiast zaangażowanego w podróżniczy aspekt społeczności? Ten drugi sposób rozumienia tego, kim jest couchsurfer, najwyraźniej ujawnił się przy okazji analizy motywacji couchsurferów do uczestnictwa w życiu warszawskiej społeczności. Sądzę, że dopiero prześledzenie treści negocjowanych w obrębie lokalnych społeczności couchsurfingowych pozwala w pełni zrozumieć, że znaczenia, jakie wielu użytkowników nadaje wspólnocie, wykraczają daleko poza rozumienie jej czysto w kategoriach grupy podróżników. Jedynie poprzez zanurzenie się w tej przestrzeni możliwe jest odsłonięcie couchsurfingowej „mas-

${ }^{5}$ Zjawisko to, ochrzczone mianem "sexsurfingu”, zostało przedstawione przez publicystów jako kolejny etap po tak zwanej „seksturystyce". Na przykład w reportażu we „Wprost” pojawiają się liczne wypowiedzi warszawskich couchsurferek, które wykorzystują couchsurfing jako okazję na przelotny seks (zob. Socha-Jakubowska 2014). 
ki przedstawionej przez wspólnotę światu zewnętrznemu" (Cohen 2003) - a więc domniemanego stricte podróżniczego charakteru społeczności.

\section{Warszawska społeczność couchsurfingowa}

Warszawska społeczność couchsurferów jest przestrzenią interakcji pomiędzy couchsurferami mieszkającymi w Warszawie oraz osobami, które przyjeżdżają do stolicy w trakcie podróży. Regularne spotkania, czyli główna aktywność $\mathrm{w}$ ramach działania grupy, są okazją do wymiany doświadczeń z wyjazdów, praktyki języków i zawarcia nowych znajomości.

Wystarczy spojrzenie na stronę internetową warszawskiej społeczności couchsurfingowej, żeby zauważyć szeroką gamę spotkań proponowanych przez członków wspólnoty pozostałym couchsurferom. Tematykę wielu z tych wydarzeń nie sposób określić jako spotkania podróżników; możemy tam znaleźć między innymi cotygodniowe spotkania miłośników gier planszowych, wycieczki rowerowe, warsztaty tanga, wyjścia na dyskotekę, wspólne picie piwa nad Wisłą czy wycieczki w góry. Ponadto w życie warszawskiej społeczności couchsurfingowej angażuje się coraz więcej osób niemających żadnych doświadczeń związanych z podróżowaniem przy użyciu couchsurfingu. W związku z tym, z czego wynika podkreślany przez moich rozmówców wyjątkowy charakter spotkań couchsurfingowych? Jaką rolę w ich kształcie odgrywa wątek podróży? $\mathrm{Na}$ te i inne pytania poszukam odpowiedzi poniżej.

Szeroki zakres tematyczny spotkań spotyka się z bardzo różnymi opiniami ze strony członków społeczności. Pierwsza grupa osób, którą postanowiłem wyodrębnić, zdecydowanie wyraża swoje niezadowolenie z kształtu, jaki przybierają niektóre spotkania. Tę postawę prezentują osoby utożsamiające couchsurfing przede wszystkim z podróżowaniem. Pytałem moich rozmówców o to, czy wyobrażają sobie spotkania couchsurfingowe $\mathrm{w}$ gronie osób tylko $\mathrm{z}$ jednego kraju - na przykład w przypadku warszawskiej społeczności - Polaków. Analizując różne wypowiedzi, zauważyłem ciekawą zależność. Rozmówcy rozumiejący couchsurfing przede wszystkim w kategorii społeczności podróżniczej byli bardziej skłonni do zaakceptowania takich spotkań. Twierdzili, że mimo braku obcokrajowców spotkania spełniałyby swoją rolę. Z drugiej strony osoby nieprzykładające tak dużej wagi do wątku podróżniczego i akceptujące szeroką tematykę spotkań couchsurfingowych kładły większy nacisk na wymianę międzykulturową. Jeden z moich rozmówców, który nigdy nie podróżował przy użyciu couchsurfingu, ale uczestniczy w życiu warszawskiej społeczności, stwierdza na przykład:

No cóż, cały sens jest w tym, że jest to międzynarodowa społeczność, tak? Trudno więc byłoby mi wyobrazić sobie, żeby były (na spotkaniach) osoby tylko jednego kraju (...) Gdyby tak było... nie, nie byłoby to tak interesujące, ponieważ ja jestem przede wszystkim zainteresowany dialogiem, językiem, różnicami kulturowymi (M-39-Holandia). 
Oczywiście miałem również okazję rozmawiać z couchsurferami, którzy, choć rozumieją couchsurfing głównie przez pryzmat podróży, to jednak akceptują szeroki wachlarz tematyczny spotkań:

Są też takie eventy podróżnicze, a samo doświadczenie podróżnicze, to, że mamy spotkanie kajaczki czy rowerki w niczym nie przeszkadza (...) więc naprawdę nie wiem dlaczego ludziom coś takiego przeszkadza, nie? (M-40-Polska).

W tym miejscu dochodzimy do bardzo istotnej kwestii - uważam, że u podstaw myślenia, zgodnie z którym wspólnota lokalna powinna zachować swój podróżniczy charakter, leży przekonanie o pewnych immanentnych cechach charakteryzujących podróżników. Te cechy to ciekawość i otwartość na świat i ludzi. Podążając za tą logiką - szeroki wachlarz tematyczny spotkań w naturalny sposób przyciąga również uwagę osób niezainteresowanych wątkiem podróżniczym. W tej grupie zaś szansa na spotkanie ludzi nieodznaczających się taką otwartością i ciekawością świata jest, zgodnie z tym rozumowaniem, dużo większa. W przedstawiony tutaj sposób myślenia wpisane jest silnie przekonanie o tym, że couchsurfingowa społeczność lokalna jest nośnikiem wartości couchsurfingowych - obraz wspólnoty, jaki nowy członek wyniesie z doświadczeń w obrębie społeczności lokalnej, przełoży się bezpośrednio na to, jak będzie on rozumiał couchsurfingową społeczność. Przyjrzyjmy się poniższej wypowiedzi:

Myślałam, że o Jezu jacy tam ludzie będą, ale stwierdziłam, no dobra pójdę, udowodnię jej, że było beznadziejnie i już nie przyjdę, niech mi da święty spokój.(...) Natomiast okazało się, że pierwsze spotkanie zrobiło na mnie wielkie wrażenie, że właśnie te... ludzie z najróżniejszych zakątków świata snuli różne opowieści (...) Więc faktycznie to wszystko zrobiło na mnie wrażenie i odtąd stałam się regularnym członkiem, powiedzmy regularnie zaczęłam udzielać się w tej społeczności (K-28-Polska).

Nowy członek społeczności, przychodząc pierwszy raz na spotkanie couchsurfingowe, często nie wie, czego się spodziewać. Przychodzi bez wstępnych założeń na temat charakteru wspólnoty. Wszystko to, z czym spotka się na miejscu, będzie miało swoje przełożenie na jego rozumienie couchsurfingu i sylwetki couchsurfera. Pytając moich rozmówców o to, co najbardziej podoba im się w spotkaniach, mogłem tylko utwierdzić się w przekonaniu, że to właśnie owa ciekawość i wynikająca z niej otwartość oraz bezpośredniość wpisane w relacje między couchsurferami są tymi elementami, które stanowią dla moich rozmówców o wyjątkowości wspólnoty couchsurfingowej. Poniżej chciałbym przytoczyć wypowiedzi stanowiące dobrą ilustrację tych przekonań. Na przykład Rafael, 29-letni Hiszpan pracujący w Warszawie, stwierdza:

Jeśli idziesz przez ulicę w Warszawie czy jakimkolwiek dużym mieście, każdy jest zajęty sobą, idą do pracy i nie zatrzymasz kogoś, jeśli nie wiesz kim jest, żeby z nim porozmawiać. Może ta osoba wcale nie chce rozmawiać. Jeśli jesteś na 
spotkaniu couchsurfingowym wiesz, że ludzie są tam właśnie, żeby rozmawiać, żeby się poznać albo żeby coś wspólnie robić. Tak więc jeśli wiesz, że macie podobne oczekiwania, to bardzo łatwo rozpocząć jakąś znajomość, w przeciwieństwie do sytuacji kiedy nawet chcesz rozmawiać, ale nie wiesz czy ktoś chce, czy nie będziesz przeszkadzał i jak zareaguje druga osoba, czy się przestraszy czy po prostu nie chce $z$ nikim rozmawiać... Tak więc na couchsurfingu wiesz, że to się nie zdarzy, że są tam osoby, które szukają trochę właśnie tego (M-29-Hiszpania).

Kolejny couchsurfer dzielący się ze mną doświadczeniem ze swojego pierwszego spotkania również podkreślił łatwość nawiązywania kontaktu z innymi couchsurferami. Brazylijczyk, będący do tej pory osobą bardzo nieśmiałą, zauważa, że dzięki pozytywnym doświadczeniom w kontakcie z couchsurferami zdecydowanie otworzył się na ludzi.

\begin{abstract}
Więc powiedziałem sobie... no tak, nie jestem zbyt społeczną osobą, zwykle czuję się onieśmielony nawet jak wychodzę do pubu ze znajomymi, nie mówiąc już o pójściu gdzieś samemu... ale skoro spotkanie odbywa się naprzeciwko mojego mieszkania, po prostu założę spodnie i pójdę tam i jeśli nie zdołam się z nikim zintegrować to zwyczajnie czegoś się napiję i wrócę do domu, jaki problem? Myślę, że to właśnie tamto doświadczenie sprawiło, że stałem się aktywnym couchsurferem, ponieważ pierwszy raz w moim życiu poszedłem do miejsca, w którym nie miałem trudności, żeby zintegrować się z ludźmi (M-29-Brazylia).
\end{abstract}

Prezentowane przeze mnie $\mathrm{w}$ tej części artykułu cechy couchsurfera oraz będący konsekwencją tych cech charakter interakcji między członkami grupy $\mathrm{w}$ trakcie spotkań warszawskich stanowią jedynie pewien model - są wizją społeczności, która, jak pokazują moje doświadczenia, często bardziej niż jej rzeczywisty kształt odzwierciedla oczekiwania couchsurferów i pozwala określić pierwotne wartości, w które wielu wciąż wierzy i które uosabia. Wielokrotnie bowiem na spotkaniach warszawskich miałem okazję być świadkiem sytuacji, które przeczyły tej utopijnej wizji. Szeroki zakres tematyczny spotkań couchsurfingowych oraz fakt ogłaszania ich od jakiegoś czasu na Facebooku sprawiają, że coraz częściej można na nich spotkać osoby nieposiadające konta na Couchsurfing.com. Na jednym ze spotkań rozmawiałem na przykład z chłopakiem, który z uśmiechem na twarzy mówił, że nie interesują go podróże, a przyszedł na wydarzenie, ponieważ nie wiedział co zrobić $\mathrm{z}$ wolnym czasem. Gdy opowiadałem mu o swoich doświadczeniach z podróży, w pewnym momencie odwrócił się do mnie plecami i zaczął rozmawiać z inną osobą. Powołując się na wypowiedź jednej z moich rozmówczyń: „Każdemu kto był w tym dłużej, to zapala się lampka, że to nie jest moja grupa" (K-30-Polska).

W dalszej części artykułu postaram się zarysować szerszy kontekst, w jakim można umiejscowić couchsurfingowe społeczności lokalne. 


\section{Couchsurfingowa społeczność lokalna jako oddolnie działający projekt wymiany międzykulturowej}

W tej części tekstu będę dowodził, że couchsurfing nie tylko zrewolucjonizował sposób, w jaki możemy podróżować. Moim zdaniem projekt couchsurfingowy stwarza zupełnie nowy kontekst, w ramach którego możemy badać tematykę migracji w dzisiejszych czasach. Couchsurferzy są dziś zarejestrowani w ponad 100 tysiącach miast na całym świecie. We wszystkich większych ośrodkach europejskich działają społeczności lokalne na kształt wspólnoty warszawskiej. Jak pokazują moje badania, owe społeczności mogą być niezastąpionym narzędziem dla wielu osób stawiających swoje pierwsze kroki w nowym miejscu zamieszkania. W przestrzeni couchsurfingowej mogą one dużo łatwiej zawierać nowe znajomości, poznawać kulturę oraz język kraju przyjmującego, a także liczyć na pomoc i bezinteresowność couchsurferów. W trakcie badań miałem okazję zaobserwować, jak codzienne życie wielu obcokrajowców mieszkających w Warszawie jest nierozerwalnie związane ze stołeczną społecznością couchsurferów. Jako przykład może posłużyć historia dwóch młodych Hiszpanów, którzy przyjechali do Warszawy w poszukiwaniu pracy. Do stolicy Polski przyjechali w 2013 r. Wybór padł na Warszawę, ponieważ mieszkał tu ich znajomy, który zaoferował im pomoc w odnalezieniu się w nowej rzeczywistości i znalezieniu pracy. Niestety, los chciał, że tuż po tym, jak przyjechali do Warszawy, wspomniany kolega z przyczyn osobistych musiał wrócić do Hiszpanii. Mimo niesprzyjającego losu bohaterowie tej opowieści postanowili zostać w Polsce i poszukać szczęścia. Przez pierwszy tydzień tułali się od jednego hostelu do drugiego, jednocześnie bezskutecznie szukając zatrudnienia oraz mieszkania. W końcu ktoś w hostelu powiedział im o couchsurfingu. Podążając za radą, wysłali wiadomości, w których opisali swoją sytuację couchsurferom, którzy w profilu mieli zaznaczony aktywny status goszczenia oraz znajomość języka hiszpańskiego. W rezultacie zostali przyjęci na siedem dni przez jedną z warszawskich couchsurferek, która oprócz zakwaterowania pomogła im w znalezieniu mieszkania (wybrała się z nimi, aby obejrzeć mieszkanie oraz przeczytać umowę) oraz w kwestiach związanych z poszukiwaniem pracy. Ta opowieść jest świadectwem tego, jak duże znaczenie może w takich okolicznościach odegrać couchsurfing.

W społeczności każdy couchsurfer ma możliwość zorganizowania spotkania dla pozostałych jej członków. Część z tych spotkań organizują couchsurferzy z zagranicy, którzy w ten sposób promują kulturę swojego kraju. Przykładem takiego wydarzenia są wspomniane już przeze mnie warsztaty tanga. Do tej kategorii moglibyśmy zaliczyć również liczne spotkania kulinarne organizowane w prywatnych domach przez gospodarzy z różnych krajów, którzy zapraszają couchsurferów na wspólne przyrządzanie dań swojej kuchni. Jeszcze inny przykład stanowią cotygodniowe spotkania osób posługujących się językiem hiszpańskim - chela y español. Ich inicjatorami byli właśnie wspomniani przeze mnie Hiszpanie. Spotkania odbywają się już od dwóch lat, a często oprócz cotygodniowego spotkania w barze członkowie grupy zapraszają się wzajemnie do swoich 
mieszkań na wspólne gotowanie. Jeden z inicjatorów tych spotkań podkreśla ich przyjacielski charakter. Poniższa wypowiedź daje ciekawy obraz relacji, które potrafią wytworzyć się pomiędzy couchsurferami:

I ty być może... pierwszy raz kiedy przyszedłeś na chela y español, powiedziałeś sobie: Ale super, będę mógł poćwiczyć hiszpański, nauczyć się... Ale potem przychodzisz tam, poznajesz ludzi, nawiązujesz przyjaźnie, relacje, i sądzę, że gdybyśmy z Antonim przestali chodzić na chela (...) ludzie nie przestaliby się spotykać, ponieważ już masz tu dobrych znajomych, stworzyłeś jakieś więzi, są osoby, chciałbyś wiedzieć, co słychać u tych osób i ... spotykalibyście się (M-27-Hiszpania).

Jeszcze inny obcokrajowiec pracujący $\mathrm{w}$ Warszawie $\mathrm{w}$ ten sposób mówi o charakterze znajomości:

Prawda jest też taka, że większość osób, które znam, poznałem ich także dzięki couchsurfingowi, ale to nie znaczy, że jeśli teraz coś z nimi robię, to że to jest couchsurfing albo nie jest couchsurfing. Rozumiesz, nie? (M-29-Hiszpania).

Wydaje się więc, że couchsurfing wytwarza przestrzeń wymiany międzykulturowej - nie chodzi tu jedynie o afirmację odmienności, co może w skrajnych formach prowadzić do segregacji w imię „poszanowania” innych kultur niż nasza, lecz o rzeczywisty dialog, wspólną naukę i wzbogacanie swoich doświadczeń dzięki poznawaniu ludzi z różnych krajów, przyswajaniu odmiennych kulturowych perspektyw - taka relacja jest więc horyzontalna i symetryczna.

Do tej optymistycznej wizji, którą przedstawiam, niezbędne jest dodanie kil$\mathrm{ku}$ zastrzeżeń. Pierwsze $\mathrm{z}$ nich wiąże się z wykluczającym $\mathrm{w}$ pewnym stopniu część użytkowników ograniczeniem językowym - obowiązującym językiem wspólnoty couchsurfingowej jest język angielski. Odzwierciedlają to doskonale regulamin oraz wartości couchsurfingowe, które dostępne są na stronie tylko $\mathrm{w}$ języku angielskim, a także pretensje couchsurferów w stosunku do użytkowników zamieszczających na forum warszawskiej społeczności wiadomości w innym języku niż angielski. Po drugie, w świetle zmian, które przedstawiam dalej, dialog międzykulturowy oparty na couchsurfingowych wartościach otwartości, ciekawości i bezinteresowności wydaje się dzisiaj poważnie zagrożony.

\section{Couchsurfing a model sharing economy}

W celu zrozumienia obecności tak szerokiego wachlarza konceptualizacji w obrębie wspólnoty niezbędne jest prześledzeniu rozwoju funkcjonowania społeczności w czasie. Proponuję teraz przyjrzeć się historii couchsurfingu w kontekście organizacyjnych przemian. Couchsurfing International został założony w kwietniu 2003 roku jako organizacja non profit. Prężny rozwój portalu nie byłby możliwy bez zaangażowania ze strony członków wspólnoty. Wolontariusze poświęcili swój czas i talent, pomagając w tworzeniu i programowaniu strony 
internetowej oraz budując wspólnotę poprzez promowanie couchsurfingu $\mathrm{w}$ trakcie podróży, powoływanie do życia lokalnych społeczności oraz wprowadzanie nowych użytkowników w ideę projektu. Przede wszystkim jednak odegrali kluczową rolę przy stworzeniu i promocji zestawu wspólnych wartości. W couchsurfingowy etos, jak możemy przeczytać $\mathrm{w}$ liście wystosowanym przez couchsurferów w października $2011 \mathrm{roku}^{6}$, zostały wpisane między innymi afirmacja szeroko rozumianej różnorodności, wartość zaufania wewnątrz wspólnoty oraz bezinteresowne ofiarowywanie siebie (swojego czasu, doświadczeń, wiedzy) innym w celu tworzenia nieformalnej, egalitarnej sieci i budowania przyjaźni.

Gdy dokonuje się zmiana społeczna i w efekcie granice wspólnoty zostają naruszone, „ludzie w coraz większym stopniu uciekają się do symbolicznych zachowań, mających na celu przywrócenie granicy", jak stwierdza Cohen (2003: 192). Momentem, w którym bez wątpienia najwyraźniej można było się przekonać o poczuciu wspólnoty obecnym wśród couchsurferów, był sierpień 2011 rok, gdy Couchsurfing.com ogłosił zmianę swojego statusu na organizację for profit. We wspomnianym już liście możemy przeczytać:

Reprezentujemy w tym miejscu tysiące członków Couchsurfingu, darczyńców i wolontariuszy. Wszyscy włożyliśmy wiele wysiłku w tworzenie globalnych powiązań, zgodnie $z$ ideałami wpisanymi w Couchsurfing, organizację non profit. Trudno jest nam uwierzyć, że dochód z systemu weryfikacji był niewystarczający, aby można było prowadzić podróżniczą stronę i nie zgadzamy się, aby dary te były sprzedane inwestorom. Wierzymy, że owe dary ${ }^{7}$ należą do wspólnoty, która tę stronę stworzyła. Sądzimy, że zmiany te są naruszeniem relacji, jaka istniała między organizacją, a jej wolontariuszami i członkami. Relacji, która kształtowała Couchsurfing aż do postaci, którą miała do tej pory społeczność. Obawiamy się, że jej wartości mogą nie przetrwać ${ }^{8}$.

Podpisujący się pod listem, couchsurferzy wyrażali swoje przekonanie, że $\mathrm{w}$ świetle zmian, jakie zaszły, powinni stać się udziałowcami $\mathrm{w}$ nowej organizacji, gdyż to właśnie oni powołali ją do życia i umożliwili jej rozkwit. Jednak po licznych rozmowach z couchurferami oraz po prześledzeniu treści, które pojawiały się na forum warszawskiej społeczności, mogę stwierdzić, że dla wielu osób kluczem w tej sprawie było naruszenie wartości couchsurfingowych, stanowiących trzon wspólnoty. Te zasady to zaufanie oraz bezinteresowność.

Inna rzecz, która przykuwa uwagę $\mathrm{w}$ powyżej przytoczonym fragmencie, to obawa dotycząca wartości couchsurfingowych, które w kontekście zmiany statusu stają według couchsurferów pod znakiem zapytania. W celu wytłumaczenia tych niepokojów niezbędne będzie dokonanie kontekstualizacji zmian,

\footnotetext{
${ }^{6}$ List był protestem na zmiany, jakie zaszły w tym czasie na portalu Couchsurfing.com.

7 "Darami” (w liście użyto słowa gifts) są pieniądze wpłacone dobrowolnie przez osoby, które zdecydowały poddać się weryfikacji.

8 Pełna treść petycji dostępna na stronie: https://www.change.org; przeł. P. Hus.
} 
jakie zaszły na portalu, poprzez ujęcie projektu couchsurfingowego w kontekście szerszego zjawiska - ekonomii dzielenia się.

Ekonomia dzielenia się (sharing economy), określana również jako wspólna konsumpcja, to termin odnoszący się do nowego modelu w gospodarce, polegającego na bezpośredniej wymianie dóbr i usług między konsumentami, czy to $\mathrm{w}$ formie bezinteresownego dzielenia się, czy też $\mathrm{w}$ formie zapłaty za produkty bądź usługi. Komunikacja odbywa się w przeważającej części za pośrednictwem Internetu, poprzez specjalne serwisy internetowe. Juliet Schor (2015), od wielu lat badająca to nowe zjawisko, stwierdza, że nie sposób przedstawić jednej uniwersalnej definicji sharing economy. Zamiast więc przedstawiać szeroki wachlarz definicji proponowanych przez teoretyków, przyjrzę się różnym przejawom ekonomii dzielenia się. Podążając za charakterystyką dokonaną przez Schor we wspomnianym eseju, możemy wyróżnić cztery kategorie, w których ujawnia się omawiany model. Każda z nich jest w pewien sposób odpowiedzią na dominujący we współczesnej gospodarce model, który bazuje na posiadaniu rzeczy na własność i promuje konsumpcjonizm. Pierwszą kategorią jest krążenie dóbr (recirculation of goods). Za przykład bliski czytelnikom może tutaj posłużyć portal Allegro.pl. Jak zauważa Schor, powstanie tego typu stron jest rezultatem intensywnego nabywania tanich importowanych produktów, charakteryzującego działania konsumentów na przestrzeni ostatnich dwóch dekad, co doprowadziło do nagromadzenia niepotrzebnych, nieużywanych już przedmiotów. Kolejna kategoria wiąże się z bardziej intensywnym użytkowaniem dóbr (increased utilization of durable assets). Przykładowo portal RelayRides.com umożliwia osobom posiadającym samochód wynajmowanie go innym użytkownikom. W grupie tej mieści się również popularny portal Blablacar - platforma działająca na zasadzie tak zwanego carpoolingu. Użytkownicy odbywający podróż samochodem i posiadający wolne miejsce oferują wspólny przejazd innym osobom, które dzielą koszty podróży. Trzecia praktyka, którą dostrzega Schor, dotyczy wymiany usług. Przykładem mogą być liczne strony wymiany umiejętności, gdzie walutą za otrzymaną wiedzę jest podzielenie się inną wiedzą z użytkownikiem portalu (np. Swapit.pl). Ostatnią kategorią jest dzielenie się zasobami bądź przestrzenią w celu promowania produkcji a nie konsumpcji. W tę grupę wpisuje się choćby idea coworkingu, czyli indywidualnej bądź zespołowej pracy we wspólnie wynajmowanym lokalu, wykorzystywana przede wszystkim przez freelancerów. Doskonałą egzemplifikacją tej kategorii jest również portal Coursera.org, który oferuje bezpłatne bądź niedrogie kursy online prowadzone przez uniwersytety i instytuty naukowe, łącznie z najbardziej prestiżowymi placówkami tego typu na świecie. Na jednym ze spotkań couchsurfingowych poznałem Hindusa, który zdobył w Warszawie pracę jako informatyk, a całą wiedzę zawdzięczał takim kursom.

Przykładem platformy działającej na zasadzie sharing economy, która skutecznie przekształca dzisiejszy rynek, jest Uber. Użytkownicy tego serwisu komunikują się między sobą za pomocą aplikacji mobilnych, oferując przewozy taksówkarskie prywatnymi samochodami. Ich oferta jest na tyle konkurencyjna 
w stosunku do korporacji taksówkarskich, że w efekcie doszło do strajków taksówkarzy w wielu miastach, takich jak Paryż, Londyn, Madryt czy Berlin. Innym wielkim graczem na rynku jest portal Airbnb, który na podobnej zasadzie stanowi zagrożenie dla branży hotelarskiej. Status prawny platform działających w ramach ekonomii dzielenia się może mieć zarówno charakter non profit, jak i for profit. Platformy typu for profit (między innymi wspomniany Airbnb czy Uber) działają przy finansowym wsparciu tak zwanego venture capital. Polskie Stowarzyszenie Inwestorów Kapitałowych definiuje venture capital jako „inwestycje na niepublicznym rynku kapitałowym, w celu osiągnięcia średnio- i długoterminowych zysków z przyrostu wartości kapitału (...) są to inwestycje dokonywane we wczesnych stadiach rozwoju przedsiębiorstw, służące uruchomieniu danej spółki lub jej ekspansji" (Venture capital/private equity 2015). Jest to więc forma finansowania, w której zysk wynika z samej wartości przedsiębiorstwa, nie zaś z działalności produkcyjnej bądź usługowej. Spółka zostaje zasilona kapitałem poprzez objęcie jej akcji bądź udziałów. W rezultacie zarząd takiej spółki zwykle stara się tak nią sterować, aby maksymalizować zyski dla udziałowców.

Couchsurfing, wraz z ogłoszeniem nowego statusu w październiku 2011 r., przyjął omawiany tutaj model venture capital. Jego udziały zostały sprzedane organizacji for profit Better World Through Travel, dzisiaj znanej jako Couchsurfing International Inc. Już rok później firma została zasilona pokaźną sumą ponad 22 milionów dolarów (Gallagher 2012). Wśród inwestorów można wymienić tak poważnych partnerów, jak General Catalyst czy Benchmark (ci ostatni finansowali między innymi Twittera, Dropboxa i Instagram). Co może zrobić zarząd, aby spełnić oczekiwania swoich inwestorów i maksymalizować zyski? Couchsurfing większość dochodów zawdzięcza dobrowolnemu procesowi weryfikacji konta, którego koszt to około 19 dolarów rocznie. W związku z tym w interesie zarządu jest ciągły wzrost liczby użytkowników, a następnie przekonanie osób, które założyły konto, do poddania się weryfikacji. I rzeczywiście od 2011 r. liczba członków wspólnoty rośnie w zawrotnym tempie. Jednocześnie możemy usłyszeć liczne głosy couchsurferów, którzy twierdzą, że wraz z liczebnym wzrostem społeczności zdecydowanie spada jej jakość. Warto przytoczyć w tym miejscu pracę doktorską Simona Schopfa (2014), której część jest poświęcona prezentacji ilościowych i jakościowych badań przeprowadzonych w celu ukazania dynamiki zmian na Couchsurfingu. Jedno z pytań dotyczyło tego, czy z perspektywy osobistych doświadczeń na przestrzeni ostatnich lat (tj. lat 2011-2014) użytkownicy odczuli jakościową zmianę projektu couchsurfingowego. Tylko 17\% użytkowników posiadających konto mniej niż 3 lata stwierdziło, że jakość couchsurfingu spadła. Natomiast $w$ grupie couchsurferów ze stażem od 3 do 10 lat tego zdania było już aż 54\% użytkowników. Bardziej doświadczeni użytkownicy są rozczarowani wieloma elementami rzeczywistości couchsurfingowej: rosnącą liczbą couchsurferów szukających jedynie darmowego noclegu, wzrastającą liczbą ubogo wypełnionych profili nieposiadających żadnych referencji, wykorzystywaniem couchsurfingu jako portalu randkowego czy niespersonalizowanym charakterem couchrequestów. Na dzień 11 lipca 2015 z 43088 członków 
warszawskiej społeczności couchsurfingowej zaledwie 7714 posiadało co najmniej jedną referencję. Tymczasem osoby odpowiedzialne za kształt strony, choć upominają użytkowników o fakcie posiadania niewypełnionych profili (informacja pojawia się na stronie startowej), to robią to przede wszystkim przy okazji braku połączenia konta couchsurfingowego z Facebookiem bądź też braku weryfikacji konta (każda weryfikacja to dodatkowa opłata).

W tabeli ilustruję różnice pomiędzy pierwotnymi wartościami couchsurfingowymi a dzisiejszym charakterem funkcjonowania firmy Couchsurfing International.

Tab. 1. Charakterystyka wartości i sposobu funkcjonowania społeczności couchsurfingowej i firmy Couchsurfing International

\begin{tabular}{|l|l|}
\hline \multicolumn{1}{|c|}{ Społeczność couchsurfingowa } & \multicolumn{1}{c|}{ Couchsurfing International Inc } \\
\hline non profit, bezinteresowność & $\begin{array}{l}\text { for profit, dążenie do maksymalizacji } \\
\text { zysków }\end{array}$ \\
\hline grupa nieformalna & formalny, scentralizowany organizm \\
\hline akcent położony na jakość interakcji & akcent położony na liczbę użytkowników \\
\hline $\begin{array}{l}\text { wartość dialogu między użytkownikami, } \\
\text { horyzontalny charakter relacji }\end{array}$ & $\begin{array}{l}\text { brak dialogu pomiędzy zarządem CS } \\
\text { a użytkownikami; cenzura9 }\end{array}$ \\
\hline
\end{tabular}

Źródło: Opracowanie własne.

Komentując tę tabelę, na początek chciałbym się odnieść do ostatniego z wyszczególnionych elementów - braku dialogu. W wypowiedziach moich rozmówców, gdy odnosili się do ciała zarządzającego wspólnotą, przeważały takie określenia, jak „oni”, „ktoś” czy "góra”. Taki dyskurs odzwierciedla poczucie braku kontroli nad kształtem wspólnoty, której jest się częścią. Od 2011 r. miało miejsce wiele kontrowersyjnych decyzji podejmowanych przez zarząd. Oprócz działań związanych z cenzurą należy też wspomnieć o bardziej subtelnych działaniach, takich jak usuwanie oraz modyfikacja zestawu stron, które zawierały instrukcje dla nowych użytkowników (sekcja zwana tips) - w pierwotnej wersji były elementarzem wartości wpisanych $\mathrm{w}$ projekt couchsurfingowy oraz zawierały pakiet cennych wskazówek związanych z tym, jak być dobrym hostem.

Inny aspekt dotyczy konfliktu między jakością projektu a liczbą użytkowników. Od momentu, gdy wzrosła popularność couchsurfingu (od 2011 r.), powstały setki artykułów prasowych podejmujących temat couchsurfingu. Niestety - w dużej części są one napisane w sposób, który określiłbym jako ,język rynku”,

9 Cenzura Couchsurfingu dotyczy między innymi usuwania poszczególnych postów, usuwania grup dyskusyjnych (np. w grudniu 2012 usunięto grupę „Leaving CS for Bewelcome”, na której niezadowoleni zmianami użytkownicy dyskutowali nt. przeniesienia się na konkurencyjny portal), usuwanie kont użytkowników, którzy wyrażali swoją krytykę wobec projektu couchsurfingowego, blokowanie opcji dodawania postów na facebookowej tablicy Couchsurfingu w marcu 2013 roku. Obszerny artykuł na ten temat: (CouchSurfing Censorship 2013). 
a ich treść kształtuje wyobrażenia przyszłych couchsurferów. O ile kiedyś przeważająca część nowych użytkowników dowiadywała się o couchsurfingu dzięki innym użytkownikom, na zasadzie rekomendacji, to prowadząc badania, miałem często okazję rozmawiać z osobami, które dowiedziały się o portalu przez serwisy, takie jak Lonelyplanet czy Facebook. Przykładem tekstu, w którym ujawnia się „język rynku”, może być artykuł, który ukazał się w sierpniu 2013 r. na portalu dziennikzachodni.pl:

Coraz większym zainteresowaniem cieszą się bezpłatne noclegi oferowane przez użytkowników zarejestrowanych na portalach takich jak Couchsurfing czy Hospitality Club. Oferty w Polsce są bardzo zróżnicowane: stosunkowo łatwo jest znaleźć nocleg w dużych ośrodkach, takich jak Warszawa czy Trójmiasto, trudniej - w małych miastach. Zdarzają się też oferty gościny w nieodkrytych jeszcze dla turystów miejscach, np. w okolicach Puszczy Niepołomickiej (Couchsurfing tanim sposobem... 2013).

Osoba nieznająca wartości wymiany kulturowej przyświecającej wspólnocie couchsurferów mogłaby pomyśleć, że Couchsurfing czy Hospitality Club jest darmową wersją Airbnb. Sformułowanie „zróżnicowane oferty” mniej ma wspólnego z duchem couchsurfingu, więcej zaś z folderem biura podróży. Z dalszej części tekstu przyszły użytkownik może dowiedzieć się, że zaoszczędzenie pieniędzy jest w rzeczywistości celem samym w sobie: „Danuta Gryka w książce Pót świata z plecakiem i mężem opisuje doświadczenia z HC i CS ${ }^{10}$ (korzystała z obydwu form) głównie w Australii i Nowej Zelandii. Bo też te formy najlepiej sprawdzają się w krajach «cywilizowanych», w miarę bezpiecznych, a jednocześnie tych, gdzie hotele są stosunkowo drogie".

Ciekawe jest również rozróżnienie na z jednej strony nieformalną grupę couchsurferów, a z drugiej na sformalizowaną organizację for profit. Waga, jaką doświadczeni couchsurferzy przykładają do tej cechy couchsurfingu, ujawniała się przy okazji wypowiedzi moich rozmówców. Marcelo nie jest jedynym couchsurferem krytykującym określenie „oficjalne spotkanie”:

$\mathrm{Na}$ to środowe spotkanie oni (czyli couchsurferzy organizujący to cotygodniowe wydarzenie) wciąż mają ten sam tekst, co od kilku lat: „och, zapraszamy na oficjalne spotkanie"... tylko wiesz, co sprawia, że to wydarzenie jest bardziej "oficjalne" niż pozostałe? (M-36-Brazylia).

Podobną wrażliwość miałem okazję zaobserwować w przypadku kategorii for profit oraz non profit. Na przykład jedna z couchsurferek odnosiła się negatywnie do cotygodniowych wydarzeń kulinarnych. W ramach spotkań każdego tygodnia couchsurfer z innego kraju oferował się jako „szef kuchni” i zapraszał do swojego domu innych użytkowników na degustację zrobionych przez siebie dań. Każdy gość natomiast wpłacał składkę na jedzenie. Ten ostatni element

10 "HC" i „CS" to skróty kolejno od Hospitality Club i Couchsurfing. 
według mojej rozmówczyni wchodził w dysonans z charakterem non profit, który wciąż obowiązuje na poziomie użytkowników couchsurfingu.

Warto na koniec dodać, że w przypadku couchsurferów niezgadzających się z nową polityką firmy omawiany opór - uciekanie się do symbolicznych zachowań - przyjmuje przede wszystkim formę pasywną. Owszem, opisałem tutaj przeróżne aktywne formy sprzeciwu, jednak w przeważającej części ten opór jest bierny, co wyraża tylko coraz większą bezradność użytkowników: na profilach niektórych członków wspólnoty można przeczytać rekomendacje podobnych, lecz bardziej szanujących swoich użytkowników portali hospitality exchange. U jeszcze innych jedyna informacja, która widnieje, to sugestywna grafika "C $\mathrm{C}$ ", symbolizująca zmonetaryzowanie projektu. Również wielu z nich w ramach protestu usuwa swój couchsurfingowy profil, często przenosząc się na inny portal.

\section{Refleksja końcowa: couchsurfing jako nowoplemię?}

Na początku tekstu obiecałem, że $\mathrm{w}$ odpowiednim momencie odwołam się do myśli Michela Maffesolego. Teraz, gdy zdążyłem już przedstawić szeroki kontekst związany z couchsurfingiem, chciałbym pokrótce przybliżyć pojęcie nowoplemion, wprowadzone przez tego francuskiego socjologa ${ }^{11}$, a następnie zastanowić się nad możliwością zastosowania go do społeczności couchsurferów.

W przeciwieństwie do wielu współczesnych socjologów, akcentujących zjawisko indywidualizacji w warunkach ponowoczesności (Beck, 2002; Giddens, 2001), Maffesoli przekornie głosi odwrotną tezę, mówiąc o upadku indywidualizmu poprzez udział we współczesnych wspólnotach - tzw. nowych plemionach. Mają się one opierać przede wszystkim na intersubiektywnie odczuwanym, przeżywanym uczuciu oraz na "przyjemności bycia razem” (Maffesoli, 2008: 7). Charakteryzuje je ulotność i względnie mała formalność. Uczestnictwo w nich wiąże się z podzielaniem pewnego światopoglądu i stylu życia - uczestnictwo $\mathrm{w}$ takiej grupie kreuje więc tożsamość jednostki. Warto jednak zaznaczyć, że nie oznacza to, że indywidualizm zanika gdzieś we wspólnotowości. Chodzi tutaj bardziej o konstatację, której dokonywali już pierwsi interakcjoniści, że nasza tożsamość, nasze wyobrażenia o nas samych, konstruowane są dopiero w relacji z innymi, nie zaś poprzez jednostkowe doświadczenia czy uczucia. „Wobec egzystencjalnej anemii, pogłębianej przez zbyt zracjonalizowane społeczeństwo, plemiona akcentują pilną potrzebę empatycznego życia społecznego: podzielania uczuć, podzielania afektów" (Maffesoli 2008: 10).

Czy warszawska społeczność couchsurfingowa mogłaby być przykładem współczesnego nowoplemienia? Jej ulotność, mały stopień sformalizowania oraz

11 Pojęcie nowoplemion przyjęło się w polskiej literaturze socjologicznej za sprawą opracowań idei Michela Maffesolego przez Zygmunta Baumana. Inne stosowane określenia to „nowe plemiona” czy „neotrybalizm”. 
akcentowanie przez jej członków wspólnego „przeżywania”, „przyjemności bycia razem", sugeruje zasadność rozważenia tego pytania.

Maffesoli stwierdza, że nowe plemiona otacza swoista "aura estetyczna". Chcąc zobrazować ten termin, odwołuje się do pojęcia ",atmosfery" (Stimmung), mającego swoje korzenie $\mathrm{w}$ romantyzmie niemieckim oraz do angielskiego terminu feeling. Według francuskiego myśliciela warunkiem uczestniczenia we wspólnocie jest otwarcie się na innych i wspólne doświadczanie owej aury. To właśnie ten czar, ta "bezosobowa moc proksemii” (Maffesoli 2008: 36) sprawia, że zaczynamy utożsamiać się z grupą, odczuwać z nią solidarność.

Wbrew bowiem temu, co przyznawać było dotąd kwestią dobrego tonu, można się zgodzić, iż rozum odgrywa dość niewielką rolę w tworzeniu i rozpowszechnianiu opinii. Ich rozprzestrzenianie się, niezależnie od tego, czy mówimy o pierwszych chrześcijanach, czy też o dziewiętnastowiecznych działaczach socjalistycznych, zawdzięcza o wiele więcej mechanizmom zarażania się wspólnie przeżywanym sentymentem czy emocją (Maffesoli 2008: 37).

Wspomniany tu feeling, otwarcie się na innych i wspólne doświadczanie "aury estetycznej", pozornie zdają się dobrze oddawać atmosferę warszawskich spotkań couchsurfingowych, przeżywaną przez moich rozmówców. Przekraczając "magiczne” drzwi lokalu, w którym odbywa się couchsurfingowe wydarzenie, członkowie wspólnoty żywią wiarę w to, że zastaną tam osoby wyznające podobne wartości i styl życia. Jak jednak dowodziłem, takie przekonanie w mniejszym stopniu oddaje faktyczny stan, a bardziej odzwierciedla oczekiwania wielu osób i pozwala określić pierwotne wartości, w które wielu wciąż wierzy i potwierdza swoją postawą. Doskonale pasuje w tym miejscu komentarz Małgorzaty Dmochowskiej (2012: 68): „Nowoplemiona są właściwie ideą, obietnicą i oczekiwaniem jednomyślności. Wspólnoty te istnieją tak długo, jak długo pozostaje nadzieja, »fałszywa obietnica " owej jednomyślności".

W świetle tych słów wydaje się, że projekt couchsurfingowy od samego początku był utopią. Portal zrzesza dziś miliony użytkowników, którzy stanowią cały przekrój społeczeństwa i reprezentują przeróżne style życia i wartości. Nie brakuje użytkowników, którzy godzą się z takim rozwojem kierunku Couchsurfingu, uważając go za nieuchronną konsekwencję popularyzacji strony. Jednocześnie dostrzegają oni liczne, pozytywne konsekwencje takiej wewnętrznej różnorodności. Dzisiejszy brak ideologicznej spójności w obrębie społeczności couchsurferów jest pierwszym powodem, dla którego nie mogę nadać jej statusu nowoplemienia. Drugi argument związany jest ze stopniem zaangażowania się w życie wspólnoty. W początkowych latach istnienia projektu większość członków grupy była aktywna (hostowała bądź surfowała, udzielała się przy organizacji spotkań couchsurfingowych, uczestniczyła w nich, oprowadzała turystów po swoim mieście, tworzyła stronę, brała udział w lokalnych grupach dyskusyjnych itd.). Aktualnie odsetek osób angażujących się w życie wspólnoty jest 
dużo mniejszy. Jak natomiast zauważa Zygmunt Bauman, istnienie nowych plemion jest zależne od ciągłej inicjatywy podsycanej przez ich członków:

Muszą być budowane każdego ranka na nowo i odnawiane co godzina, płynne paliwo emocji jest jedyną krwią, jaka krąży w ich żyłach. Nikła jest więc nadzieja na to, by mogły sobie pozwolić na luksus zrezygnowania z wojowniczości i nietolerancji i wyzbyć się kompulsywnej troski o własne bezpieczeństwo (za: Dmochowska 2012: 39).

Wspomniane "płynne paliwo emocji” wciąż jednak płynie w żyłach wielu couchsurferów. Żywym dowodem na to, że couchsurfingowa utopia jest wciąż obecna $\mathrm{w}$ umysłach wielu osób jest fakt wyodrębnienia się w ostatnich latach z grupy couchsurferów nowej grupy. Jej członkowie twierdzą, że nowa przestrzeń, którą współtworzą, jest ostatnim miejscem, w którym można poczuć „ducha dawnego couchsurfingu". Elementem organizującym życie grupy są wspólne wyjazdy na tzw. campy couchsurfingowe, Każdego roku ma miejsce około 50 takich zjazdów. Trwają one zwykle od 3 do 6 dni, a każdy z nich odbywa się $\mathrm{w}$ innym miejscu. Lokalizacja zależy od gościnności lokalnych couchsurferów-wolontariuszy, którzy podejmują się organizacji wydarzenia. W campach uczestniczą użytkownicy Couchsurfingu oraz innych sieci gościnności (Bewelcome, Hospitality Club itp.), gdyż znaczenie ma podzielanie wspólnych wartości i stylu życia, nie zaś przynależność do określonego portalu. Osoby przyjeżdżające na takie campy goszczone są zwykle przez lokalnych couchsurferów. $\mathrm{W}$ trakcie takich zjazdów w ciągu dnia zapewniony jest bogaty program kulturalno-rozrywkowy (gry miejskie, zwiedzanie miasta itp.), a wieczorami odbywają się imprezy. Niektóre campy mają lokalny charakter i gromadzą kilkadziesiąt osób, inne cieszą się ogromną popularnością, skupiając nawet kilkuset uczestników. Zdecydowana większość uczestników takich campów zna się między sobą, a główną motywacją do wyjazdu na kolejny obóz jest chęć ponownego spotkania się z przyjaciółmi i odczuwanie "przyjemności bycia razem” (Maffesoli, 2008, s. 7). W większości są to osoby pamiętające czasy tworzenia się couchusurfingu i będące zdania, że kształt wspólnoty na przestrzeni lat uległ zniekształceniu.

Jedna z couchsurferek, regularnie jeżdżąca na campy, powiedziała mi, że na skalę Europy (bo to w Europie odbywa się większość zjazdów) grupę tę tworzy około 500 członków. Choć, podobnie jak w przypadku lokalnych społeczności couchsurfingowych, omawiana grupa ma inkluzywny charakter i następuje w niej płynna wymiana członków, to odróżniający element stanowi fakt, że jej trzon tworzy stała grupa osób, które spotykają się cyklicznie przy okazji campów, a tuż po powrocie $\mathrm{z}$ takich zjazdu zaraz zaczyna się ożywiona dyskusja nad najbliższym spotkaniem. „Estetyczną aurę” obecną na takich zjazdach obrazuje doskonale wypowiedź jednej z warszawskich couchsurferek:

Jedziesz tam po to, żeby przez te kilka dni intensywnie żyć, intensywnie się spotykać i odczuwać... odczuwać...odczuwać... no cały świat w jednym miejscu (...) odczuwać to, że my jesteśmy community, my jesteśmy wspólnotą, ludzie 
często mówią rodziną... i zdarzają się na przykład campy, na których... ostatnio był taki camp, gdzie praktycznie wszyscy znają wszystkich (...) kurczę, ale będzie słabo, jesteśmy jak jedna wielka rodzina. Ani tu się nie da nikogo pocałować, ani nic. Wszystkich znam, więc z siostrą się po krzakach włóczyć nie będę... więc to też było spostrzeżenie humorystyczne, ale bardzo bliskie prawdy również. Tak się czujemy (K-30-Polska).

To, co przykuwa moją uwagę w powyższej wypowiedzi, to formy czasownikowe „czujemy” i ,jesteśmy” wyrażające przynależność do grupy. Na podstawie przeprowadzonych wywiadów mogę jednoznacznie stwierdzić, że język członków warszawskiej społeczności couchusurfingowej nie odzwierciedlał podobnego poczucia jedności i solidarności. O ile społeczność couchsurfingowych campów wydaje się być doskonałą egzemplifikacją "nowych plemion”, o tyle charakter warszawskiej społeczności couchsurfingowej z większą trafnością oddaje koncepcja „wspólnoty wyobrażonej” Andersona czy „wspólnoty znaczeń” Cohena.

"Camperska” społeczność w ostatnich latach rośnie w siłę. Jednocześnie, wciąż występując pod szyldem couchsurfingu, zdaje się szukać nowej tożsamości. Co jakiś czas na Facebookowej grupie wspólnoty powracają, niczym bumerang, głosy nawołujące do utworzenia, na bazie tej społeczności, nowego portalu działającego na zasadach sieci gościnności. To właśnie tam ostatnie, pilnie chronione przez grupę ziarenko couchsurfingowych wartości miałoby wypuścić pąki i zacząć na nowo rozkwitać. Czyżby utopijny cykl miał zatoczyć koło?

\section{Literatura}

Anderson, B. (1997). Wspólnoty wyobrażone. Rozważania o źródtach i rozprzestrzenianiu się nacjonalizmu. Przeł. S. Amsterdamski. Warszawa-Kraków: Znak.

Beck, U., Beck-Gernsheim, U. (2002). Individualization. Institutionalized Individualism and its Social and Political Consequences. London: Sage.

Bialski, P., Batorski, D. (2009). From Online Familiarity to Offline Trust. How a Virtual Community Creates Familiarity and Trust between Stangers. W: P. Zaphiris i Ch.S. Ang, Social Computing and Virtual Communities. Chapman and Hall.

Cohen, A.P. (1985). The symbolic construction of Community. London: Tavistock Publications.

Cohen, A.P. (2003). Wspólnoty znaczeń, W: M. Kempna, E. Nowicka (red.), Badanie kultury. Elementy teorii antropologicznej. Przeł. K. Warmińska (s. 192-215). Warszawa: Wydawnictwo Naukowe PWN.

Couchsurfing tanim sposobem na wakacyjny wyjazd (2013). http:/ / www.dziennikzachodni.pl /artykul/973179,couchsurfing-tanim-sposobem-nawakacyjnywyjazd,id,t.html [dostęp: 21.08.2013].

Dmochowska, M. (2012). Nowe wspólnoty w Polsce na przełomie XX i XXI wieku. Między Platonem, Amwayem a trollami. Warszawa: IFiS PAN.

Frykowski, M. (2007). Zaufanie społeczne mieszkańców Łodzi. Łódź: Wyd. UŁ.

Gallagher, B. (2012), Couchsurfing Raises \$15 Million Series B From General Catalyst Partners, Menjo Ventures, Others, http://techcrunch.com/2012/08/22/couchsurfingraises-15-million-series-b-from-general-catalyst-partners-others [dostęp: 20.07.2015]. 
Giddens, A. (2001). Nowoczesność $i$ tożsamość. „Ja" i społeczeństwo w epoce późnej nowoczesności. Przeł. A. Szulżycka. Warszawa: Wydawnictwo Naukowe PWN.

Gnevosa, S. (2011). Phenomenon of Couchsurfing as alternative tourism. Tuluza.

Lauterbach, D. (red.). (2009). Surfing a web of trust: Reputation and Reciprocity on CouchSurfing.Com. International Conference on Computational Science and Engineering. Vancouver.

Maffesoli, M. (2008). Czas plemion. Schyłek indywidualizmu w społeczeństwach ponowoczesnych. Przeł. M. Bucholc. Warszawa: Wydawnictwo Naukowe PWN.

Picard, D., Buchberger, S. (eds.) (2013). Couchsurfing Cosmopolitanisms. Can Tourism Make a Better World? Bielefeld: Transcript Verlag.

Rosen, D. (2011). CouchSurfing: Belonging and trust in a globally cooperative online social network. New Media \& Society, 13(6), 981-998.

Ross, L. (1977). The false consensus effect: An egocentric bias in social perception and attribution processes. Journal of Experimental Social Psychology, 13(3), 279-301.

Schopf, S. (2014). The Commodification of the Couch. The Commons vs. Commodification: A Dialectical Analysis of Hospitality Exchange Networks. Uniwersytet w Uppsali.

Schor, J. (2014). Debating the Sharing Economy. http://www. greattransition.org/publication/debating-the-sharing-economy [dostęp: 01.08.2015].

Socha-Jakubowska, P. (2014). Sexsurfing po polsku. http://www.wprost.pl/ar/438190/ Sexsurfing-po-polsku/ [dostęp: 14.07.2015].

Wężyk, K. (2014). O lewicowych marzeniach i ciężkich pieniądzach. http://wyborcza.pl/magazyn/1,140582,16594618,O_lewicowych_marzeniach_i_ciezkich_pieniadzach.html [dostęp: 14.02.2015].

Venture capital / private equity, http://www.pi.gov.pl/Finanse/chapter_95011.asp [dostęp: 28.07.2015].

\section{Źródła internetowe:}

https://www.change.org/p/petition-against-the-new-legal-status-of-couchsurfing [dostęp: 28.07.2015]

http://www.couchsurfing.com

https://infogr.am/couchsurfing-statistics [dostęp: 24.10.2015]

http://en.wikipedia.org/wiki/CouchSurfing

http://couchwiki.org/en/CouchSurfing_censorship [dostęp: 02.09.2015]

\section{SUMMARY}

A community of meaning or a new tribe? Ethnographic study of the couchsurfing community in Warsaw

The goal of this paper is to describe the community of couchsurfers - members of the hospitality exchange website Couchsurfing.com. The article is the result of a 2-year-long ethnographic fieldwork that I conducted among the members of Warsaw couchsurfing community. The analysis finds its basis in a conceptual theory of "symbolic community" (Cohen, 1985). Not only do I try to show the aspect of using the website for travelling purpose (which is present in many papers on Couchsurfing), but I also explore the context of local communities of couchsurfers. Through this I show that it is exactly where the process of negotiation and definition of the couchusurfing values and principles takes place. I also focus on the emerging concerns caused by the change of the financial model 
of Couchsurfing.com in 2011 and I try to present a broad repertoire of symbolic devices used by couchsurfers in order to affirm and reinforce the boundaries of their community.

Keywords: couchsurfing, symbolic community, neotribalism, sharing economy 